\title{
ПСИХОЛІНГВІСТИЧНІ МАРКЕРИ УЯВЛЕННЯ ПІДЛІТКІВ ПРО СПЕЦИФІКУ ПРОФЕСІЙ ФІНАНСОВОГО АНАЛІТИКА, ЛІКАРЯ, УЧИТЕЛЯ ТА ПСИХОЛОГА \\ (на прикладі аналізу запитань уявного інтерв'ю)
}

Psycholinguistic Markers of Adolescent Presentation on the Specifics of the Professions of Financial Analyst, Doctor, Teacher and Psychologist (on the Example of the Analysis of Imaginary Interview Questions)

\author{
Hanna Kholod \\ Ph.D. in Philological, Deputy Director for Educational Work \\ O.S. Pushkin Gymnasium № 153 (Kyiv, Ukraine) \\ kholodanna@ukr.net \\ https://orcid.org/0000-0002-2479-9721
}

\begin{abstract}
The purpose of the study is to find out the psycholinguistic markers of adolescents' perceptions about the specifics of the professions of financial analyst, doctor, teacher and psychologist (on the example of the analysis of imaginary interview questions).

Students of 8th grades of Kyiv gymnasium offered a questionnaire on career guidance, among the questions was the task of participating in an imaginary interview with such representatives of the profession as a financial analyst, psychologist, doctor, teacher, and ask them questions. Then the questions analyzed and psycholinguistic markers identified, with the help of which the collective images of the representatives of the above-mentioned professions, formed in the imagination of adolescents, modeled.
\end{abstract}

Key words: psycholinguistic markers, interview, profession, financial analyst, doctor, teacher, psychologist.

\section{Ветуп}

Introduction

Визначення 3 майбутньою професією є актуальною проблемою (із 39 опитаних гімназистів 24 не визначилися 3 майбутньою професією) для багатьох сучасних підлітків. Важливе завдання допрофільної підготовки учня - створити умови для того, щоб учень, ураховуючи результати психологічного тестування, свої здібності, 
інтереси, проведені профорієнтаційні заходи, свідомо обрав свою професію й реалізувався як професіонал у сфері своєї діяльності. У контексті сказаного важливо постійно з'ясовувати, які уявлення про професії формуються в підлітків у результаті їхнього життєвого досвіду та інформації, отриманої з різних джерел.

Мета дослідження - 3'ясувати психолінгвістичні маркери уявлення підлітків про специфіку професій фінансового аналітика, лікаря, учителя та психолога (на прикладі аналізу запитань уявного інтерв’ю).

\section{Методи та методики дослідження}

\section{Methods and Techniques of the Research}

Під час дослідження було використано такі методи: описовий метод, аналіз, синтез, узагальнення, експеримент із використанням анкетування.

Методика. Досліджуваним віком 13-14 років (учням 8-х класів київської гімназіі) був запропонований експеримент 3 елементами анкетування на профорієнтаційну тематику. За інструкцією було завдання стати учасниками уявного інтерв’ю з такими представниками професії, як фінансовий аналітик, психолог, лікар, учитель, і поставити їм запитання. За результатами аналізу отриманих реакцій було виокремлено психолінгвістичні маркери, за допомогою яких було змодельовано збірні образи представників вищезазначених професій, сформовані в уявленні підлітків.

В уявленні досліджуваних професії лікаря, учителя, психолога є важкими через велике комунікативне коло й постійну роботу 3 людьми. Професія фінансового аналітика асоціюється з успіхом та прибутками.

\section{Результати \\ Results}

Під час експерименту було опитано 39 (100.0\%) осіб віком 13-14 років (учнів, які навчаються у 8 класах і яким викладають курс за вибором «Фінансова грамотність»). 16 (41.0\%) досліджуваних не поставили б під час уявного інтерв'ю запитання фінансовому аналітику. На нашу думку, такий факт можна пояснити декількома причинами: відсутністю достатніх знань про згадану професію, відсутністю інтересу до фінансової сфери, зосередженням уваги на вже обраній професії. Після аналізу реакцій досліджуваних за допомогою психолінгвістичних маркерів було здійснено моделювання уявлення підлітків про специфіку професії фінансового аналітика та створити його портрет, ураховуючи особливості сприйняття підлітками вищезазначеної професії. Троє (7.6\%) досліджуваних цікавляться розміром 
заробітної плати фінансового аналітика, припускаючи, можливо, великий рівень щорічного доходу. Наприклад, учасник експерименту за кодом 13, який хоче стати учителем, вважає професію нудною. Психолінгвістичним маркером такого уявлення $\epsilon$ використана в запитанні («Чи не набридає ця робота?») лексема «набридає», що 3'явилася через антитетичні уявлення про професії учителя та фінансового аналітика за критерієм «кількість учасників комунікаційного кола». В учителя воно широке, оскільки представник цієї професії спілкується з учнями, батьками, колегами, а у фінансового аналітика, який переважно опрацьовує документи, комунікаційне коло вузьке, на відміну від учителя. Ще одним психолінгвістичним маркером уявлення підлітків про професію фінансового аналітика $є$ лексема «складна» (Наскільки складна Ваша професія?). У запитанні учасника експерименту «Як досягти успіху в тій чи іншій справі?» виокремлюємо лексему «успіх», яка в комплексі 3 комунікаційною ситуацією (звернення із цим запитанням саме до фінансового аналітика, а не до інших представників професії, зокрема лікаря, учителя, психолога), $\epsilon$ психолінгвістичним маркером. Учасник експерименту, майбутній юрист, поставив запитання (Які закони обов'язково треба запам'ятати?) фінансовому аналітикові 3 позиції обраної ним професії, що, на нашу думку, презентує свідомий вибір майбутньої професії. Інша учасниця експерименту, яка хоче стати актрисою, ставлячи запитання фінансовому аналітикові, акцент зробила саме на своїй професії, щоб 3'ясувати ставлення до неї. За допомогою вищезазначених психолінгвістичних маркерів можемо змоделювати збірний образ фінансового аналітика, який формується в уявленні сучасних підлітків. Це успішна людина, яка має вузьке комунікативне коло, високий рівень річного доходу й виконує складні завдання. Незважаючи на такі уявлення про професію, жоден із тих учнів, хто визначився 3 професією, не обрав професію фінансового аналітика. Вважаємо, що такий результат зумовлений або відсутністю достатньої інформації про цю професію, або нестабільним економічним становищем нашої держави, що призводить до неможливості повної самореалізації в цій професії.

$10(25.6 \%)$ учасників експерименту не поставили б запитання лікарю, у 12 (30.7\%) респондентів у запитаннях було використано лексем «важко», «складно», «труднощі», «найскладнішим», що стосувалися не лише виконання обов’язків лікаря, а й періоду здобуття освіти. Лексему «страх» в запитаннях щодо відповідальності за життя пацієнта використали два учні (5.1\%). Крім того, до вищезазначеної теми мають відношення лексеми «відповідальність» («Бути лікарем - це велика відповідальність») і «сміливість» («Потрібна сміливість у Вашій сфері»), використані не в запитаннях, а твердженнях респондентів, розміщених або перед запитанням, або після нього. Отже, виокремлені психолінгвістичні маркери моделюють образ лікаря, 
який формується в уявленні сучасних підлітків віком 13-14 років. Це смілива людина, яка бере на себе відповідальність за життя інших людей, долає труднощі як під час здобуття освіти, так і під час професійної діяльності. Зазначимо, що 5 (12.8\%) респондентів хочуть стати лікарями.

15 (38.4\%) учасників експерименту не поставили б запитання психологу під час уявного інтерв’ю, 3 (7.6\%) респонденти поставили б запитання («Як працювати 3 дітьми?», «Як бути душею компанії?», «Яку літературу Ви порадите прочитати?»), які окреслюють коло їхніх зацікавлень, а не специфіки професії психолога. У реакціях запитань 6 (15.3\%) учасників експерименту використано лексеми «допомагати», «проблеми», «людям» (різні форми), що, на нашу думку, є психологічними маркерами уявлення про основне завдання представника вищезгаданої професії надати психологічну допомогу. У запитаннях 5 (12.8\%) учасників експерименту $є$ лексема «важко», що свідчить про усвідомлення підлітками факту нелегкої роботи 3 людьми. Отже, на підставі виокремлених психолінгвістичних маркерів змодельовано такий образ психолога: він, виконуючи нелегкі завдання, допомагає людям розв'язувати психологічні проблеми. Зауважимо, що один (2.5\%) учасник експерименту хоче стати психологом.

15 (38.4\%) респондентів не поставили б запитання вчителю під час уявного інтерв’ю, 8 (20.5\%) учасників експерименту в запитаннях, адресованих учителю, використали лексеми «важко», «терпите», «складно» у контексті роботи з дітьми. Такі психолінгвістичні маркери презентують уявлення підлітків про роботу вчителя як складну. Відзначимо, що один (2.5\%) учасник експерименту хоче стати вчителем.

\section{Висновки}

Conclusions

(1). Найбільша кількість досліджуваних віком 13-14 років (восьмикласниківгімназистів), які вже визначилися або не визначилися з майбутньою професією, поставила б запитання лікарю під час уявного інтерв'ю з представником професії.

(2). 26\%, 38\%, 38\%, 39\% учасників експерименту не поставили б запитання лікарю, психологу, учителю, фінансовому аналітику, що зумовлено або відсутністю/наявністю зацікавлення конкретною професією, або відсутністю достатніх знань про цю професію.

(3). Виокремлені із запитань уявного інтерв’ю психолінгвістичні маркери дозволяють змоделювати збірні образи фінансового аналітика, психолога, лікаря, учителя, сформовані в уявленні підлітків про представників вищезазначених професій. 
Psycholinguistics in a Modern World - 2020. Proceedings of the 15th International Scientific and Practical Conference (Pereiaslav-Khmelnytskyi, 22-23 October, 2020)

(4). Професія вчителя та психолога в уявленні підлітків віком 13-14 років є складною через учасників комунікації (відповідно діти та люди 3 психологічними проблемами).

(5). Професія лікаря в уявленні підлітків є складною через умови роботи та відповідальність, яку представник вищезазначеної професії бере на себе за життя пацієнтів.

(6). Професія фінансового аналітика в уявленні деяких підлітків пов'язана 3 успіхом, роботою з документами, високою заробітною платою. 